Jurnal At-Tibyan: Jurnal Ilmu Alqur'an dan Tafsir

Volume 5 No. 2, Desember 2020 (h.171-193)

P ISSN 2442-594X | E ISSN 2579-5708

http://journal.iainlangsa.ac.id/index.php/tibyan

\title{
THE SYSTEMATIC INSCRIPTIVE OF BUGINES INTERPRETATION BOOK: COMPARATIVE ANALYSIS BETWEEN TAFSÎR AL-MUNÎR AND TAFSÎR AL- QUR'ÂN AL-KARÎM
}

\author{
Muhammad Dzal Anshar \\ Kementerian Agama Sulawesi Selatan, Indonesia \\ dzalanshar@gmail.com
}

Hasyim Haddade

Universitas Islam Negeri Alauddin Makassar, Indonesia hasyim.haddade@uin-alauddin.ac.id

\begin{tabular}{|l|l|l|}
\hline \multicolumn{3}{|c|}{ DOI 10.32505/jurnal at-tibyan.v5i2.1469 } \\
\hline Submitted: 07-03-2020 & Revised: 01-10-2020 & Accepted: 17-10-2020 \\
\hline
\end{tabular}

\begin{abstract}
The Books of Tafsîr al-Munîr and Tafsîr al-Qurān al-Karîm are the books which compiled using Lontara script and Bugis language fully interpreting 30 Juz of Qur'ān. This research is a qualitative descriptive method which applied in the discipline of interpretation (Tafsîr) known as Muqāran by comparing two books of interpretation (Tafsir) that are considered commensurate in order to review the differences and similarities methods used. In the systematics of the presentation, it can be concluded that the main difference between the two Books of Tafsir Bugis is in the introduction of the interpretation (Tafsîr), whereas in Tafsîr al-Qur'ān al-Karîm begins by explaining the general description of the surah, which contains the number of surah verses, the reason for the surah name and the main topic of the surah, while in Tafsir al-Munir directly listed the verse and translation it with the title of the surah name and the number of verses at the top. In the content section of the interpretation has generally similarities in the two books of interpretation by grouping several verses based on a specific theme, in the closing section of the difference significant is found in the closing juz, each juz in Tafsir al-Munîr is closed with "Alhamdulillah", which different from Tafsîr al-Qur'ān al-Karîm, which closed with "wallāhu a'lam bi al-sawāb".
\end{abstract}

Keywords: Tafsir Systematics, Bugis Tafsir, Comparative.

Hak Cipta @ 2020. Dimiliki oleh Penulis, dipublikasikan oleh Jurnal At-Tibyan: Jurnal Ilmu Alqur'an dan Tafsir. Artikel dengan akses terbuka. Lisenci: CC-BY

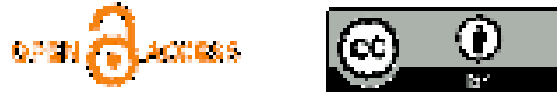




\begin{abstract}
Abstrak
Kitab Tafsir al-Munïr dan Kitab Tafsìr al-Qur'ān al-Karim, adalah diantara kitab tafsir yang disusun menggunakan aksara lontara dan berbahasa Bugis lengkap menafsirkan 30 Juz al-Qur'an. Penelitian ini adalah penelitian kualitatif yang bersifat deskriptif Metode yang digunakan pada penelitian ini dalam disiplin ilmu tafsir dikenal dengan istilah muqāran, yakni membandingkan dua kitab tafsir yang dianggap sepadan kemudian megkaji perbedaan dan persamaan metode yang digunakan. Dalam sistematika penyajian dapat disimpulkan bahwa perbedaan utama antara dua Kitab Tafsir Bugis ialah pada bagian pendahuluan tafsir, dimana pada Tafsir al-Qur'ān alKarim dimulai dengan menjelaskan gambaran umum surah, yang berisi jumlah ayat surah, alasan nama surah dan topik utama surah, sedangkan pada Tafsir al-Munir langsung dicantumkan ayat dan terjemahnya dengan judul nama surah dan jumlah ayat dibagian atas, pada bagian isi tafsir secara umum terdapat kesamaan pada kedua kitab tafsir yakni dengan mengelompokkan beberapa ayat berdasarkan tema tertentu, pada bagian penutup perbedaan siginifikan terdapat pada penutup juz, Tafsir al-Munir setiap juz ditutup dengan ungkapan "alhamdulillah", adapun pada Tafsìr al-Qur'ān al-Karim, ditutup dengan ungkapan "wallāhu a'lam bi al-sawāb".
\end{abstract}

Kata Kunci: Sistematika Tafsir, Tafsir Bugis, Komparatif.

\title{
Pendahuluan
}

Jauh sebelum munculnya kitab tafsir dalam bahasa Bugis yang menjadi simbol kejayaan dan indikator tingginya semangat dan daya literasi masyarakat Bugis di Sulawesi Selatan, pada rentan abad ke-7 hingga 10 M., masyarakat bugis sudah akrab dengan tradisi tulis menulis yang ditandai dengan penemuan Sastra dan literasi Bugis kuno seperti Sure' Galigo, Lontara', Papaseng Toriolota yakni pesan-pesan nenek moyang terdahulu, dan Elong-kelong atau syair. Diprakarsai oleh beberapa lembaga, Kementerian Pendidikan dan Kebudayaan bekerja sama dengan Pemerintah Daerah Sulawesi Selatan, manuskrip yang tersimpan di Belanda itu akhirnya dapat dibuka kembali, sastra Bugis kuno ini diketahui merupakan epos terpanjang di dunia, ditulis dengan menggunakan huruf lontar. ${ }^{1}$

Penjelasan sebelumnya menandakan jejak tradisi sastra-literal masyarakat bugis yang kuat, bahkan sebelum islam masuk ke Sulawesi Selatan. Menurut Cristian Pelras, seorang pakar sejarah dan kebudayaan bugis berkebangsaan Perancis, masyarakat Sulawesi Selatan sudah mengenal ajaran islam sejak awal abad ke-17. ${ }^{2}$ Sejak itu, khazanah keilmuan islam di Sulawesi Selatan terus mengalami kemajuan, salah satu lembaga pendidikan islam tertua di Sulawesi Selatan yang paling terkenal adalah

\footnotetext{
${ }^{1}$ Muhammad Bakar Akkase Teng, Filsafat Dan Sastra Lokal (Bugis) Dalam Perspektif Sejarah,

${ }^{2}$ Lihat Christian Pelras, Manusia Bugis, diterjemahkan oleh, Abdil Rahman Abu, Hasriadi, dan Nuhardy Sirimorok, (Jakarta: Nalar \& Forum Jakarta-Paris: 2006), 148
} 
Madrasah 'Arabiyah Islamiyah (MAI) Sengkang, dirintis oleh AG. ${ }^{3}$ H. Muhammad As'ad pada Mei 1930 bertepatan dengan bulan Zulqa'iddah 1348 H. sepulangnya dari madrasah Al-Falah Mekkah pada tahun 1928, dari lembaga pendidikan itu, lahir sejumlah Ulama Bugis yang berperan penting menyusun kitab-kitab tafsir berbahasa Bugis yang disusun menggunakan aksara lontara' diantaranya AG. H. Abdurrahman Ambo Dalle, di Mangkoso' Kab. Barru, AG. H. M. Daud Ismail, Kab. Soppeng, AG. H. Yunus Maratan, dan AG. H. Muhammad Abduh Pabbaja. ${ }^{4}$

Diantara kitab tafsir yang disusun dengan aksara lontara dan berbahasa bugis

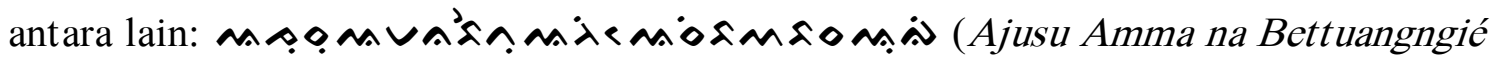
Sibawa Basa Ugi / Juz 'Amma Terjemahnya dalam Bahasa Bugis), disusun oleh AGH.

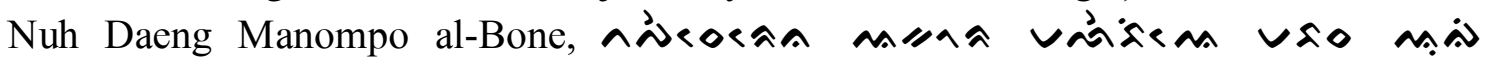
(Tapeséréna Akorang Malebbié Mabbasa Ugi) / Tafsir al-Qur'an al-Karim Berbahasa

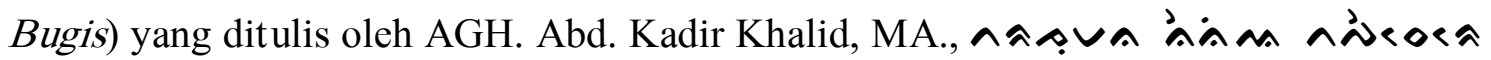

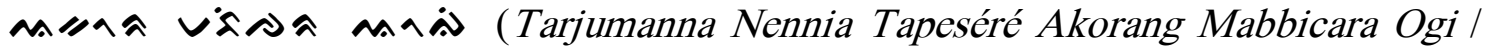
Terjemah dan Tafsir al-Qur'an Bahasa Bugis) yang disusun oleh AGH. Daud Ismail di Soppeng dibantu oleh AGH. Hamzah Manguluang yang menulis naskah Juz ke-30, dan

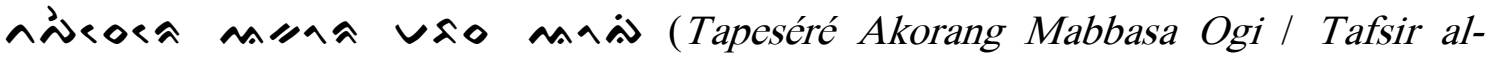
Qur'an Berbahasa Bugis) yang merupakan karya tim MUI Sul-Sel diketuai oleh AGH. Abd. Muin Yusuf, yang saat itu menjabat sebagai ketua MUI. ${ }^{5}$

Terdapat beberapa kajian sebelumnya tentang penerjemahan al-Qur'an dalam bahasa daerah diantaranya Fadhli Lukman yang menulis tentang studi kritis atas teori tarjamah al-Qur'an dalam 'Ulum Al-Qur'an. ${ }^{6}$ Artikel ini fokus pada pembahasan tentang konsep tarjamah ditinjau dari aspek teoritis. Egi Sukma Baihaki juga melakukan penelitian proses penerjemahan al-Qur'an di Indonesia tahun $2017 .^{7}$ Dalam artikel yang ditulis oleh Egi Sukma Baihaki membahas secara normatif dan informatif mengenai hal ihwal seputar cakupan kajian terjemahan (Al-Qur'an). Dua artikel ini

\footnotetext{
${ }^{3}$ Anre Gurutta' adalah sebuah istilah gelar penghormatan dan pengakuan bagi ulama Sulawesi Selatan yang berpengaruh besar dan mendapat kepercayaan masyarakat dalam pemahaman keagamaannya, lazimnya sebutan ini populer dalam lingkup pondok pesantren, digunakan oleh para santri sebagai istilah untuk menunjuk kepada ulama atau pimpinan dan pembina pondok pesantren, biasanya mereka yang mendapat gelar Anre Gurutta diliputi dengan kisah-kisah ajaib dan menakjubkan tentang keutamaan mereka sejalan degan makna karāmah dan irhas bagi orang saleh, hal itu melengkapi karisma dan marwah Anre Gurutta dimata masyarakat umum, pada perkembangannya, setelah para santri menjadi alumni pondok pesantren dan menyebar ke masyarakat dengan membawa almamaternya masing-masing gelar Anre Gurutta kemudian populer dan digunakan ole masyarakat umum, penggunaan gelar itu sama dengan gelar kiyai di Jawa, Buya di Minang, Tuan Guru di Banjarmasin dan Nusa Tenggara Barat. Selengkapnya baca Wahidin Ar-Raffany, AG. H. Abdul Muin Yusuf; Ulama Kharismatik Dari Sidenrang Rappang, Cet. I, (Sidrap: LAKPESDAM SIDRAP, 2008).

${ }^{4}$ Abd. Muiz Kabry, Sejarah Kebangkitan dan Perkembangan Darud Da'wah wal Irsyad (DDI), (Pondok Pesantren DDI Ujung Lare, Pare-Pare: 1983), 4

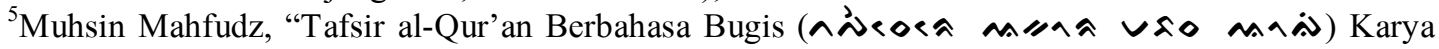
AGH. Abd. Muin Yusuf”. AL-FIKR: Jurnal Pemikiran Islam 15 no. 1 (2011): 34- 47.

${ }^{6}$ Fadhli Lukman," Studi Kritis Atas Teori Tarjamah Al-Qur'an dalam 'Ulumul Qur'an”, Al-A 'raf: Jurnal Pemikiran Islam dan Filsafat 13 no. 2 (2016): 167-190. http://10.22515/ajpif.v13i2.262

7 Egi Sukma Baihaki, 'Penerjemahan Al-Qur'an: Proses Penerjemahan Al-Qur'an di Indonesia, Jurnal Ushuluddin, 25, no. 1 (2017): 44-53. http://dx.doi.org/10.24014/jush.v25i1.2339
} 
penting untuk mengantarkan pembaca pada gambaran umum teori dalam penerjemahan khususnya penerjemahan al-Qur'an.

Produk terjemahan al-Qur'an dalam bahasa daerah (Indonesia) juga dikaji oleh Hanapi Nst. ${ }^{8}$ Artikel ini membahas tentang metodologi Terjemahan Al-Qur'an dalam Al-Qur'an dan Terjemahnya Bahasa Batak Angkola. Sementara Yani Heryani ${ }^{9}$ mengkaji tentang teknik penerjemahan al-Qur'an dengan bahasa daerah yaitu Sunda. Jajang A. Rohmana ${ }^{10}$ juga menkaji tentang respon generasi Milenial terhadap penerjemahan al-Qur'an dengan bahasa Sunda.

Kajian terhadap penerjemahan al-Qur'an dalam bahasa Bugis ditulis oleh Mursalim dan Abbas. ${ }^{11}$ Dengan mengambil tokoh Anregurutta Yunus Maratan, Mursalim menunjukkan bahwa karya tersebut merupakan sebuah upaya untuk menjembatani antara al-Qur' an sebagai teks yang berbahasa Arab dengan masyarakat Bugis awam yang tidak paham terhadap bahasa asal al-Qur'an (Arab). Adapun secara metodologis karya itu bukanlah sebagai sebuah literatur tafsir seperti literatur-literatur tafsir mainstream, melainkan hanya sebagai sebuah karya terjemahan al-Qur'an yang memadukan antara tarjamah lafziyah dan tafsiriyah. Fenomena itu sekaligus membuktikan bahwa sejarah penyebaran dakwah Islam di Nusantara, khususnya di Sulawesi Selatan sangat fleksibel dengan melibatkan berbagai unsur-unsur lokal sebagai media dakwah, termasuk vernakularisasi al-Qur'an. Itulah sebabnya antara karya ulama Bugis dengan konteks budaya masyarakat saling berkelindan dalam membentuk budaya Islam lokal.

Berdasarkan pada telaah terhadap kajian-kajian di atas, artikel yang penulis tulis ini, memiliki nilai beda. Nilai beda tersebut adalah pada aspek kajiannnya yang melakukan perbandingan antara penerjemahan al-Qur'an pada "Tafsir al-Munir karya A.G.H. Daud Ismail dengan Tafsir al-Qur'ān al-Karim karya AGH. Abdul Muin Yusuf.

Penelitian ini bertujuan untuk membandingkan sistematika penyajian tafsir Bugis dengan menemukan persamaan dan perbedaan metode penyajian dalam kitab tersebut, metode penelitian seperti ini dalam disiplin ilmu tafsir dikenal dengan istilah analisis komparatif. ${ }^{12}$ Dalam metodologi tafsir istilah komparasi identik dengan muqāran, ${ }^{13}$

\footnotetext{
${ }^{8}$ Hanapi Nst, “Metodologi Terjemahan Al-Qur'an dalam Al-Qur'an dan Terjemahnya Bahasa Batak Angkola", Kontemplasi: Jurnal Ilmu-ilmu Ushuluddin 7, no. 01 (2019): 1-18. https://doi.org/10.21274/ kontem.2019.7.1.1-18

9 Yani Heryani, “Teknik Menerjemahan Al-Qur'an Ke Dalam Bahasa Sunda”, Al-Tsaqafa: Jurnal Ilmu Peradaban Islam 16 no. 2 (2019): 167-175. https://doi.org/10.15575/al-tsaqafa.v16i2.5018

${ }^{10}$ Jajang A. Rohmana, "Alquran Dan Bahasa Sunda Populer: Respons Generasi Milenial Terhadap Terjemahan Alquran Bahasa Sunda" Al-Bayan: Jurnal Studi Al-Qur'an dan Tafsir 4 no. 2 (2019): 93110. https://doi.org/10.15575/al-bayan.v4i2.8008

11 Mursalin dan Abbas, "Vernakularisasi Al-Qur'an di Tanah Bugis: Tinjauan Metodologis Terjemahan Al-Qur'an Karya Anregurutta Yunus Maratan” Al-Izzah: Jurnal Hasil-hasil Penelitian 15 no. 2 (2020): 49-62. http://dx.doi.org/10.31332/ai.v0i0.2179

${ }^{12}$ Suharsimi Arikunto, Prosedur Penelitian : Suatu Pendekatan Praktek. (Jakarta : Rineka Cipta. 1998), 236

${ }^{13}$ Abdul Hayy al-Farmawy, Al-Bidāyah fi Tafsìr al-Mauḍū'ī; Dirāsah Manhajiyah Maudūùiyah, terj. Rosihan Anwar, Metode Tafsir Maudū'i, Dan Cara Penerapannya, diterj. Rosihan Anwar, Cet. I, ( Bandung: Pustaka Setia, 2002), 23.
} 
adalah metode yang menjelaskan ayat-ayat al-Qur'an dengan merujuk pada penjelasanpenjelasan para mufasir, ${ }^{14}$ yang menekankan pada aspek perbandingan tafsir AlQur'an. ${ }^{15}$ Menurut Nasruddin Baidan metode komparatif atau muqāran diantaranya: 1) membandingkan ayat al-Qur'an yang memiliki kemiripan redaksi dan membicarakan satu kasus yang sama atau diduga sama; 2) membandingkan ayat al-Qur'an dan hadis Nabi saw, yang secara tekstual terlihat bertentangan; 3) membandingkan berbagai pendapat mufassir dalam menjelaskan makna ayat-ayat al-Qur'an. ${ }^{16}$ Secara praktis Metode muqāran digunakan untuk mengungkap ayat Al-Qur'an yang mempunyai topik yang sama tetapi redaksi yang berbeda, atau redaksi yang sama dengan topik yang berbeda, ${ }^{17}$

Dalam penelitian ini peneliti sedikit memodifikasi metode tersebut dengan membandingkan dua metodologi kitab tafsir brdasarkan Sistematika penyajian tafsir hal ini meliputi, langkah-langkah yang dilakukan setiap mengawali dan mengakhiri penafsiran dalam satu surah dan hal-hal apa saja yang dicantumkan dalam penafsiran surah atau ayat.

\section{Biografi Penyusun Tafsir Bugis}

\section{Biografi Penyusun Tafsī al-Munir}

Terdapat dua versi sehubungan dengan tanggal lahir AGH. Daud Ismail lahir berdasarkan penelitian Abd. Kadir Ahmad dalam disertasinya "Ulama dalam Dinamika Sosial Sulawesi Selatan”, AGH. Daud Ismail lahir pada tanggal 31 Desember 1907 di Cenrana, Desa Ompo, kecamatan Lalabata Kabupaten Soppeng. ${ }^{18}$ Sedang berdasarkan penelitian Muhyiddin dalam disertasinya "Tafsir al-Munir, Studi atas Pemikiran Akhlak A.G.H. Daud Ismail", disebutkan bahwa AGH. Daud Ismail dilahirkan pada tanggal 30 Desember 1908 M. dan wafat di usia 99 tahun, hari senin tanggal 22 Agustus 2006, dikebumikan di Pondok Pesantren Yasrib Watansoppeng. ${ }^{19}$ Sehubungan dengan perbedaan data tentang tanggal lahir tersebut yang dapat diperpegangi adalah penelitian oleh Abd. Kadir Ahmad karena penelitian tersebut dilakukan pada kurun waktu Juni 2002 sampai bulan Oktober 2004, yakni pada masa AGH. Daud Ismail masih hidup, sehingga informasi yang didapatkan lebih kuat.

Ia memang terlahir dari keluarga Ulama, kakeknya bernama Kali Qadi Adam atau yang lebih dekenal dengan panggilan Kali Soppeng adalah merupakan Qadi pertama di Soppeng, ${ }^{20}$ Lembaga pendidikan yang dirintis AGH Daud Ismail yang masih tetap eksis sampai sekarang diantaranya Yayasan Perguruan Islam Boewe

\footnotetext{
${ }^{14}$ Al-Farmawi, Al-Bidāyah fî Tafsìr al-Mauḍū'ī, 39.

${ }^{15}$ M. Fatih Suryadilaga, Metodologi Ilmu Tafsir, (Yogyakarta: Teras, 2005), 46.

${ }^{16}$ Nasruddin Baidan, Metode Penafsiran Al-Qur'an (Yogyakarta: Pustaka Pelajar, 2002), h. 59-60

${ }^{17}$ Suryadilaga, Metodologi Ilmu Tafsir, 47.

${ }^{18}$ Abd. Kadir Ahmad, Ulama dalam Dinamika Sosial Sulawesi Selatan, Disertasi (Makassar: PPs. Universitas Hasanuddin Makassar, 2005), 203.

${ }^{19}$ Muhyiddin, Tafsìr al-Munìr, Studi atas Pemikiran Akhlak AG.H. Daud Ismail, Disertasi, (Makassar: PPs UIN Alauddin, 2010), 58-64.

${ }^{20}$ Ahmad, Ulama dalam Dinamika Sosial Sulawesi Selatan, 203.
} 
(YASRIB) di Watan soppeng, serta pada tanggal 1 Agustus 1932 mendirikan Madrasah Annajahiyyah didirikan AGH. Daud Ismail bersama masyarakat di Pattojo Soppeng. Pada tahun 1952 AGH. Daud Ismail mengabdikan diri di almamaternya, Madrasah Arabiyah Islamiyah MAI) Sengkang. Oleh sebuah tim yang terdiri dari beberapa alumni senior MAI, ia disepakati untuk memimpin lembaga tersebut menyusul wafatnya AGH. M. As'ad. AGH. Daud Ismail mengusulkan perubahan nama dari Madrasah Arabiyah Islamiyah MAI) menjadi Madrasah As'adiyah, sebagai penghargaan kepada sang guru, Kepemimpinan beliau berakhir tahun 1961. ${ }^{21}$

Adapun karya AGH. Daud Ismail selain Tafsir al-Munir diantaranya: a) Pengetahuan Dasar Agama Islam, berjumlah 3 jilid; b) Al-Ta'n̄ f bi al-Alim al-'Allāmah al-Syaykh al Häjji Muhammad As'ad al-Bugisisi;

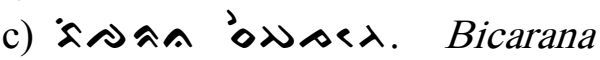

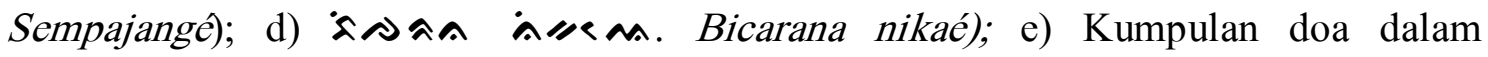
kehidupan sehari-hari; f) Kumpulan khutbah Jum'at berbahasa Bugis); g) Kumpulan doa sehari-hari.

\section{Biografi Penyusun Tafsir al-Qur'ān al-Karim}

Tafsir Tafsìr al-Qur'ān al-Karīm merupakan ide dan prakarsa AGH. Abdul Muin Yusuf, pada saat itu beliau memangku amanah sebagai ketua Majelis Ulama Indonesia (MUI) Sulawesi Selatan, yang berlangsung dua periode 1985-1990 dan 1990-1995, karena menganggap penting adanya kitab tafsir berbahasa bugis untuk memudahkan masyarakat bugis dalam memahami makna ayat al-Qur'an, maka beliau membentuk satu tim penyusun beranggotakan beberapa ulama di Sulawesi Selatan untuk menyusun sebuah kitab tafsir dalam bahasa bugis. Berikut dipaparkan biografi singkat AGH. Abdul Muin Yusuf dan para ulama yang berperan dalam penyusunan kitab tafsir berbahasa Bugis ini sebagaimana disebutkan dalam muqaddimah Kitab Tafsìr alQur'ān al-Karim. $^{22}$

AGH. Abdul Muin Yusuf dilahirkan pada tanggal 21 Mei 1920 di Rappang, Kabupaten Sidrap, yang juga merupakan tanah kelahiran M. Qurais Shihab, seorang pakar tafsir Indonesia yang populer saat ini, Anre Gurutta lahir dari pasangan bersuku Bugis, ayahnya Muhammad Yusuf berasal dari desa Bulu Patila, Sengkang, kabupaten Wajo dan ibunya Sitti Khadijah dari Rappang, kabupaten Sidrap, memasuki usia 10 tahun, beliau menimbah ilmu umum di lembaga pendidikan formal yakni Inlandsche School, merupakan lembaga pendidikan setingkat Sekolah Dasar yang terkenal pada zaman pendudukan Belanda di Sulawesi Selatan di waktu pagi dan di sore harinya untuk memperkaya ilmu agamanya beliau bergabung sebagai peserta didik di Madrasah Ainur Rafie pimpinan Syekh Ali Mathar dan menyelesaikan pendidikannya pada tahun 1933, melanjutkan pendidikannya ditingkat tsanawiyahsMP, Anre Gurutta menuju sengkang untuk bergabung di Madrasah Arabiyah Islamiyah (MAI) di kabupaten Wajo,

\footnotetext{
${ }^{21}$ Ahmad, 204-205.

${ }^{22}$ Majelis Ulama Indonesia Sulawesi-Selatan, Tapesere Akorang Mabbasa Ogi, Jilid 1 (Ujung Pandang: MUI Sul-Sel, 1988), 4.
} 
Madrasah tersebut didirikan dan dipimpin oleh AGH. Muhammad As'ad, kemudian dikenal sebagai Pondok Pesantren As'adiyah Sengkang, dinisbahkan pada nama AGH. Muhammad As'ad, tamat pada tahun 1937, Abdul Muin remaja melanjutkan pendidikannya di lembaga pendidikan Normal Islam Majene pada tahun1939 Sulawesi Barat, yang kemudian berubah nama menjadi Mu'allimat Ulya dan berpindah ke Kab. Pinrang, Abdul Muin menyelesaikan studinya disana tahun 1942, sepulangnya ke Sidrap beliau kemudian diangkat sebagai Qadhi atau seorang hakim dalam urusan agama dalam sebuah pemerintahan, namun pada tahun 1947 beliau melepaskan jabatan tersebut untuk berangkat ke Makkah menunaikan ibadah haji, pada saat di Makkah inilah pintu gerbang untuk mendapatkan ilmu pengetahuan yang lebih luas terbuka, saat itu Daru Falah sebuah perguruan tinggi di Arab Saudi membuka penerimaan mahasiswa baru kesempatan itu kemudian beliau manfaatkan dengan mengikuti seleksi sehingga lulus dan terdaftar sebagai mahasiswa, hanya dalam kurun waktu 2 tahun menempuh pendidikan disana, pada tahun 1949 Anre Gurutta menyelesaikan studinya, beliau kemudian kembali ke tanah air dan mendirikan beberapa lembaga pendidikan seperti Madrasah Tarbiyah Islamiyah (MTI) pada tahun 1949, Sekolah Menengah Islam yang kemudian berubah menjadi Sekolah Guru Islam Atas (SGIA) dan berkembang menjadi Sekolah Persiapan IAIN, dan akhirnya pada tahun 1974 Anre Gurutta mendirikan pondok pesantren Al Urwatul Wutsqa di kecamatan Baranti Kab. Sidrap, "di pondok pesantren inilah saya mewaqafkan sisa hidup saya" demikian ucapan Anre Gurutta yang sering ia sampaikan pada santrinya. ${ }^{23}$

AGH. Ma'mur Ali dikenal sebagai seorang ulama berafiliasi Muhammdiyah dan merupakan purnawirawan TNI, dilahirkan di Barru pada hari selasa tanggal 13 Maret 1923, di usia 10 tahun beliau menyelesaikan pendidikan dasarnya di Volk School desa Lisu, Tanete Riaja, Kab. Barru, kemudian menempuh pendidikan di Foor Volk School, pada tahun 1937, Ia mendaftar tentara pada tahun 1949 dan lulus dengan pangkat Letda kemudian menjabat sebagai PA. Rohis Komando Pangkalan Kodam XIV Hasanuddin (saat ini Wirabuana) dan berbagai jabatan di TNI pernah diembannya sampai beliau pensiun di Kostrad Pusat tahun 1982, beberapa amanah yang pernah ia emban diantaranya: Anggota DPRD Sulawesi Selatan tahun 1960, Direktur Muallimin yahun 1951-1960, Ketua MUI periode 1961-1969, Dekan FISIPOL Unversitas Muhammadiyah Makassar 1965-1969, Direktur Pon-Pes Darul Arqam Gombara tahun 1992 dan Wakil Ketua Pakar ICMI Sul-sel 1992, sepulang dari tanah suci mengikuti pengajian di DDI Mangkoso sebelumnya bernama Madrash Arabiyah Islamiyah/MAI) di bawah asuhan Anrégurutta Ambo Dalle. Dari sinilah beliau mendapatkan pengetahuan agama yang nantinya mengantarkan beliau menjadi seorang ulama. Setelah menimbah ilmu di abwah asuhan Anrégurutta Ambo Dalle, beliau memutuskan

\footnotetext{
${ }^{23}$ Muhammad Ruslan dan Waspada Santing, ed., Ulama Sulawesi Selatan: Biografi Pendidikan dan Dakwah (Cet. I; Makassar: Komisi Informasi dan Komunikasi MUI Sulawesi Selatan, 2007), 73-77.
} 
untuk melanjutkan pendidikannya di Muallimin Makassar pada tahun 1938. Pada tahun 1967 menyelesaikan studi S1 di IAIN sekarang UIN Syarif Hidayatullah Jakarta. ${ }^{24}$

AGH. Hamzah Manguluang lahir pada tahun 1925 di Sengkang kabupaten Wajo, Beliau adalah salah satu murid Anrégurutta AGH. Muhammad As'ad, disebabkan kemampuannya menghafal kitab Al-Fiyat Ibn Malik sekaligus dengan syarahnya, beliau dianggap sebagai murid Anrégurutta yang pintar dan sangat cerdas, sebagai salah seorang murid utama Anrégurutta dan menjadi salah satu ulama berpengaruh karena pengabdiannya di Pesantren As'adiyah, Hamzah Manguluang dianggap layak untuk ditunjuk sebagai anggota tim penyusun kitab Tafsir bugis, beliau wafat pada tahun 1998 diantara karyanya selain kitab tafsir bugis yakni: Sallu kamā raaytumūni ușali dan terjemah dan tafsir kitab Wasiyyah al-Qayyimah merupakan kitab syair arab yang diterjemahkan oleh AGH. MuhammadAs'ad dalam bahasa Bugis. ${ }^{25}$

AGH. Muhammad Djunaid Sulaiman terkenal sebagai ulama keturunan bangsawan yang konon mengkhatamkan al-Qur'an sebanyak 1.841 kali, beliau adalah ulama karismatik yang dihormati dan dikagumi masyarakat Bone. Lahir di desa Kading, kecamatan Awangpone, Kabupaten Bone, tanggal 19 Agustus 1921 M/14 Zulhijjah $1339 \mathrm{H}$, wafat pada usia 75 tahun tepatnya pada tanggal 7 Desember 1996 M/27 Rajab $1417 \mathrm{H}$, dan dikuburkan di pekuburan keluarga besarnya Talumae Watampone Bone sesuai dengan wasiatnya, beliau merupakan keturunan ulama dari ayahnya Sulaiman, seorang Qadi kerajaan Bone ke 15 periode tahun 1946-1951, dan kakeknya KH. Adam, yang juga Qadi kerajaan Bone ke 9 periode 1847-1865, Semasa hidupnya didampingi oleh seorang istri bernama Andi Sampewali binti Andi Ope Cangkung, yang kemudian diganti namanya menjadi Andi Dania oleh AGH. Junaid Sulaiman pada saat dipersunting di usia 11 tahun. Kedua pasangan ini dikaruniai 16 orang anak, yang hidup hanya $10 .{ }^{26}$ Pada masa kecil Djunaid Sulaiman mendapatkan pengetahuan agama di pondok pesantren Awampone, pada usia 13 tahun ia bersama saudaranya diutus ke Mekkah untuk menuntut ilmu disana selama kurang lebih 13 tahun dan tinggal di rumah pamannya Syekh Abdul Rahman Bugis, selama di Mekkah beliau mendapatkan ilmu secara tradisional dari ulama dan secara klasikal di Madrasah Al-Shawlatiyyah, setelah menghapal al-Qur' an dalam kurun waktu satu tahu, pada usia 15 tahun beliau mengkhatamkan hafalannya dan termasuk sebagai murid berprestasi dengan predikat rangking satu. Setelah tamat, disamping menjadi tenaga pendidik, beliau juga aktivis organisasi pemuda pejuang Kemerdekaan RI di Mekkah, dan akhirnya pada tahun 1947 beliau kembali ke tanah air di kampung asalnya Awampone pada awal kedatangannya beliau mengabdi sebagai kepala Madrasah Amriyah Islamiyah yang sekarang dikenal sebagai Perguruan Tinggi Al Ghazali, ia dikenal

\footnotetext{
${ }^{24} \mathrm{Hj}$. Marahumah, Istri Alm. AGH. Ma'mur Ali, Wawancara oleh Mursalim, Makassar 18 Maret 2008. Mursalim, “Corak Pemikiran Tafsir Ulama Bugis (Suatu Kajian Kitab Tafsir al-Qur'an Karim Karya Majelis Ulama Indonesia (MUI) Sulawesi Selatan”, Disertasi, 40-42.

${ }^{25}$ Mursalim, 39-40.

${ }^{26}$ Muhammad Ruslan dan Waspada Santing, ed., Ulama Sulawesi Selatan: Biografi Pendidikan dan Dakwah, 168 dan 171.
} 
seorang yang sosialis dan aktif sebagai pendakwah dan pembina masyarakat dengan mengadakan program-program islam kemasyarakatan, salah satu pesannya yang banyak dikutip ialah "dua waktu yang tidak boleh diharapkan yaitu masa lalu dan masa yang akan datang". Pada tahun 1972 yang saat itu AGH. Junaid Sulaiman menjabat sebagai Ketua MUI Sul-sel bersama dengan Panglima Kodam VII Wirabuana, memprakarsai berdirinya Ma'had Hadis Biru di bawah Yayasan Pesantren Modern (YASPEM), yaitu Abdul aziz. Mulanya pesantren ini didirikan sebagai pesantren Tahfiz al-Qur'an, tetapi kemudian semakin populer dan banyak diminati, sehingga dibentuk sistem madrasah, mulai dari tingkat anak-anak Rawdah al-Atfäl, setingkat SMP yakni Śanawiyah, hingga Aliyah/SMA. ${ }^{27}$

Latar Belakang Penyusunan Tafsir Bugis

Tafsir al-Munïr atau dikenal juga Kitab Tarjumanna Nennia Tapeséré Akorang Mabbicara Ogil Terjemah dan Tafsir al-Qur'an Bahasa Bugis, dikerjakan selama 14 tahun, dari tahun 1980 hingga 1994. Selama waktu penulisan AGH Daud Ismail dibantu oleh koleganya AGH. Hamzah Manguluang yang menulis naskah Juz ke-30, AGH. Ismail Husain, menulis beberapa juz sebelum Anregurutta Daud wafat, dan Gurutta M. As'ad al-Yafie yang menulis 21 juz selama kurang lebih 10 tahun, setelah para penulis naskah tersebut dipanggil oleh yang Maha Kuasa maka kegiatan penulisan dilanjutkan oleh Gurutta Drs. Khuzaimah. ${ }^{28}$ Tafsir al-Munir, adalah kitab tafsir menggunakan bahasa daerah Bugis dan ditulis dalam aksara lontara Bugis, lengkap 30 juz yang merupakan karya monumental AGH. Daud Ismail sebagai salah seorang ulama karismatik yang dikenal di Sulawesi selatan.

Adapun Tapeséré Akorang Mabbasa Ogi / Tafsir al-Qur'an Berbahasa Bugis yang lebih dikenal Tafsìr al-Qur'ān al-Karìm, kemudian belakangan juga dikenal dengan nama Tafsīr al-Mu'in sebagaimana yang diterbitkan oleh PP Al-Urwatul Wutsqa Benteng Sidrap yakni Pondok Pesantren yang di asuh oleh AGH. Abdul Mu'in Yusuf, $^{29}$ merupakan ide dan prakarsa AGH. Abdul Muin Yusuf yang saat itu menjadi ketua Majelis Ulama Indonesia (MUI) Sulawesi selatan, selama dua periode 19851990 dan 1990-1995) Ia kemudian membentuk satu tim penyusun yang terdiri dari beberapa ulama di Sulawesi-Selatan dalam penulisan kitab tafsir tersebut. ${ }^{30}$

Pada dasarnya tujuan penyusunan kedua kitab tafsir Bugis tersebut adalah untuk memberikan pemahaman terhadap masyarakat Bugis pada saat itu tentang penafsiran al-Qur'an, namun apabila ditelaah lebih dalam pada muqaddimah tafsir keduanya alasan utama penyusunan Tafsīr al-Munir karya AGH. Daud Ismail sebagai kitab yang disusun lebih dulu, ialah karena beliau melihat belum ada kitab tafsir berbahasa bugis lengkap 30 juz yang disusun pada saat itu, adapun alasan utama AGH. Abdul Muin

\footnotetext{
${ }^{27}$ Ruslan dan Santing, ed, 123-127.

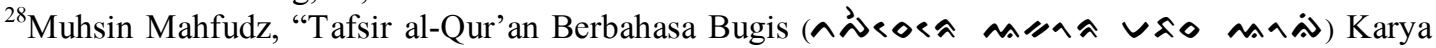
AGH. Abd. Muin Yusuf." AL-FIKR 14, no. 3 (2010), 34-47.

${ }^{29}$ Selengkapnya baca Wahidin Ar-Raffany, AG. H. Abdul Muin Yusuf; Ulama Kharismatik Dari Sidenrang Rappang,

${ }^{30}$ Majelis Ulama Indonesia Sulawesi-Selatan, Tapesere, 4
} 
Yusuf sebagai ketua tim penyusun Tafsīr al-Qur'ān al-Karim, menyatakan bahwa tujuan penyusunan tafsir tersebut adalah meringankan dan melepas beban sebagai ulama Bugis dari amanah agama yang bersifat sosial dan fardu Kifayah. ${ }^{31}$

\section{Karakteristik Umum Kitab Tafsir Bugis}

Kedua kitab tersebut merupakan kitab tafsir berbahasa Bugis terlengkap menafsirkan 30 juz al-Qur'an yang dapat dijumpai sampai saat ini, hal tersebut disebabkan karena kitab-kitab tersebut terus dikaji dari berbagai aspeknya sehingga para penelitinya berinisiatif untuk memperbanyak dan melestarikan kitab tersebut baik dengan cara di scan untuk disimpan sebagai arsip digital maupun dicetak ulang

\section{Kitab Tafsï al-Munir}

Kitab tafsir ini memiliki dua bentuk cetakan yang pertama dalam setiap jilid hanya berisi 1 juz diterbitkan oleh CV. BINTANG SELATAN offset, pada tahun 1984, cetakan kedua berjumlah 10 jilid dalam setiap jilid ditafsirkan 3 juz, oleh CV. Bintang Lamumpatue pada tahun 2001, secara fisik cetakan tahun 1984 oleh CV. BINTANG SELATAN offset, memiliki sampul berwarna biru dengan judul kitab Tarjumah wa alTafsir, kemudian menuliskan juz yang ditafsirkan dan nama penyusun dalam tulisan Arab, hal tersebut berbeda dengan cetakan kedua oleh CV. Bintang Lamumpatue tahun 2001, yang umum dijumpai memiliki sampul berwarna coklat, meskipun terdapat juga warna lain seperti merah, judul kitab dengan tulisan berwarna putih yakni Tafsir alMunir, serta menyebutkan juz dan nama penyusun dengan tulisan Arab, kemudian

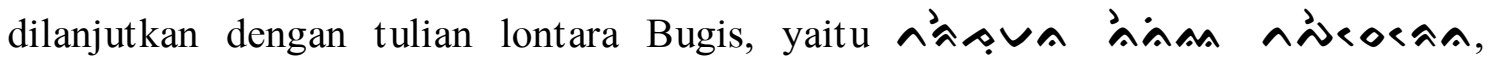
dilanjutkan dengan menyebut juz yang ditafsirkan pada jiid tersebut serta nama penulis dengan huruf lontara Bugis dan pada bagian bawah menyebutkan jilid kitab. ${ }^{32}$ Modelnya dapat dilihat pada gambar no. 1 berikut:

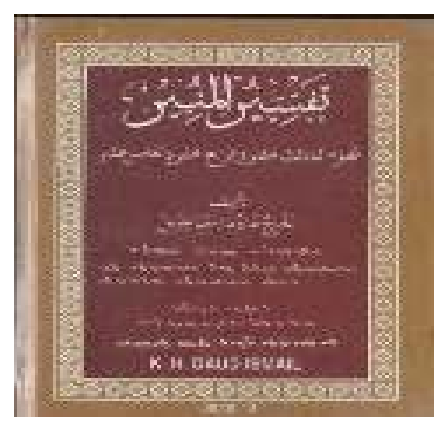

Gambar no.1: Kitab Tafsïr al-Munïr

\section{Kitab Tafsīr al-Qur'ān al-Karim}

Dari segi fisik, judul kitab tafsir ini tercantum pada bagian paling atas berwarna

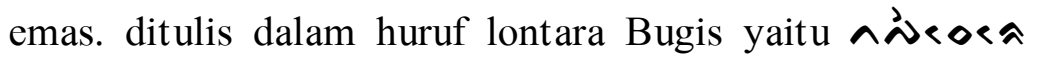

\footnotetext{
${ }^{31}$ Lihat Daud Ismail, Tafsïr al-Munïr, Juz 1, (Makassar: CV. Bintang Lamumpatue, 2001), 4-6; Majelis Ulama Indonesia Sulawesi-Selatan, Tapesere, 1.

${ }^{32}$ Lihat K.H. Daud Ismail, Tarjumah wa al-Tafsir, (Ujung Pandang: CV. BINTANG SELATAN, 1984); bandingkan K.H. Daud Ismail, Tafsir al-Munïr, (Makassar: CV. Bintang Lamumpatue 2001).
} 
(Tapeséré Akorang Mabbasa Ogi) yang berarti tafsir al-Qur'an berbahasa bugis, tepat dibawah judul kitab terdapat lingkaran yang pada bagian dalamnya tertulis Tafsir alQur'ān al-Karim dalam bahasa Arab, kemudian pada bagian menyebutkan nomor jilid, karena ditulis oleh tim maka nama penulis tidak dicantumkan, kemudian disebutkan

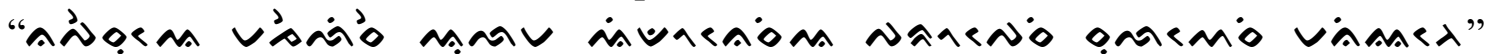
yang artinya diterbitkan oleh Majelis Ulama Indonesia propinsi Sulawesi selatan,

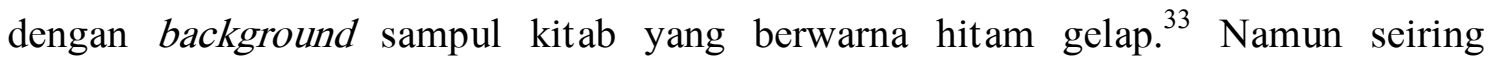
perjalanan waktu kitab tersebut dicetak juga oleh penerbit PP Al-Urwatul Wutsqa Benteng Sidrap yakni Pondok Pesantren yang di asuh oleh AGH. Abdul Mu'in Yusuf, bekerja sama dengan pemerintah kabupaten Sidrap dan diberi nama Tafsir al-Mu'in, dinisbahkan pada nama Gurutta sebagai bentuk penghargaan kepada AGH. Abdul Mu'in Yusuf, penerbitan tersebut bekerja sama dengan pemerintah kabupaten sidrap ${ }^{34}$ Berbeda dengan terbitan MUI Sul-sel, kitab terbitan PP Al-'Urwatul Wutsqa memiliki ciri fisik sampul berwarna kuning dengan judul kitab Tafï al-Mu'ín ditulis dalam bahasa Arab. Model sampul kedua kitab tersebut dapat dilihat pada gambar no. 2 berikut:

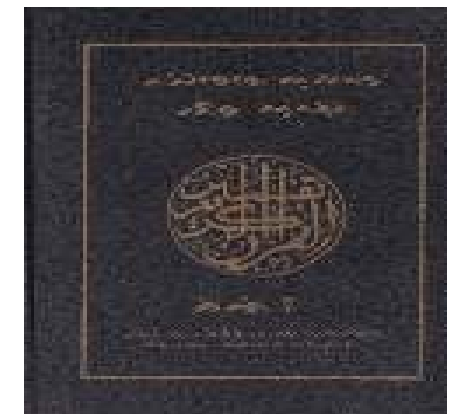

厂经路

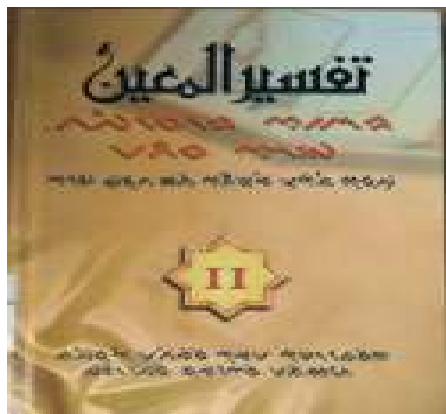

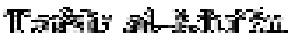

Gambar No. 2: Gambar Sampul Tafsiri al-Munir dan Tafsìr al-Qur'ān al-Karim

\section{Metodologi Kitab Tafsir Bugis}

Metode tafsir yang dimaksud disini adalah berdasarkan empat metode yang ditetapkan oleh Al-Farmawi yakni: ${ }^{35}$ Tahlili analisis yang rinci terhadap kandungan ayat), ${ }^{36}$ Muqāan membandingkan penafsiran ayat dengan yang lainnya atau mufassir

\footnotetext{
${ }^{33}$ Muhsin Mahfudz, Transformasi Tafsir Lokal, Upaya Pemetaan Metodologi Karya Tafsir Ulama Sulawesi Selatan (1930-1998), Disertasi (Makassar: PPs. UIN Alauddin, 2015), 153.

${ }^{34}$ Penjelasannya mengenai penerbitan kitab terdapat pada sampul belakang kitab Tafsir al-Mu'inn, juga menampilkan foto KH. Abdul Muin Yusuf, lihat KH. Abdul Muin Yusuf, Tafsir al-Mu'īn, Tapeséré Akorang Mabbasa Ogi (Sidrap: PP Al-Urwatul Wutsqa, t.th); baca juga Wahidin Ar-Raffany, $A G$. $H$. Abdul Muin Yusuf; Ulama Kharismatik Dari Sidenrang Rappang,

${ }^{35}$ ، Abdul al-Hayy al-Farmawi, Muqaddimah fì al-Tafsìr al-Maudū'i (Kairo: Al-Hadārah al-Arabiyyah, 1977), 23

${ }^{36}$ Metode Tajzi adalah metode yang mufasirnya berusaha menjelaskan kandungan ayat-ayat AlQur'an dari berbagai seginya dengan memperhatikan ayat-ayat sebagaimana yang tercantum dalam mushaf. Lihat M. Quraish Shihab, Membumikan Al-Qur'an; Fungsi dan Peran Wahyu dalam Kehidupan, Cet. XIII. (Bandung, Mizan, 1998), 86.
} 
yang satu dengan mufassir lainnya), ${ }^{37}$ Ijmāli penafsiran yang bersifat umum dan disajikan secara ringkas, ${ }^{38}$ dan Mauḍ̂̀'i penafsiran berdasarkan tema-tema tertentu). ${ }^{39}$ Mengingat kitab tafsir Bugis termasuk dalam kitab yang disusun diera modern dan banyak mengutip kitab tafsir sebelumnya, maka pada dasarnya kedua kitab tafsir Bugis menerapkan keempat metode tersebut.

Jika dilihat dari aspek penyajiannya, Kitab Tafsir al-Munir dan Kitab Tafsir alQur'ān al-Karìm termasuk dalam kategori metode tafsir Taḥlili, yang disajikan secara runut, ${ }^{40}$ sesuai dengan urutan surah dalam mushaf Usmani, yaitu tafsir surah dimulai dari al-Fātihạ hingga al-Nās. ${ }^{41}$ meskipun dari aspek penyajian tafsir surahnya termasuk dalam kategori Tahlifi,. Jika dilihat dari segi uraian-urain ayat yang dijelaskan, secara analisis kedua kitab ini menggunakan metode Ijmāli, metode ijmăi digunakan oleh para mufassir dengan penjelasan yang sesuai dengan konteks ayat yang ditafsirkan dan tidak terlalu melebar sehingga memudahkan untuk dipahami. ${ }^{42}$ Tujuan utama metode ini adalah memudahkan pengkaji al-Qur'an dan pembaca kitab tafsir dalam memahami kandungan ayat dan surah dalam al-Qur'an sebagai petunjuk.

\section{Analisis Komparatif Sistematika Penyajian Tafsir Bugis \\ Pendahuluan Tafsir.}

Pendahuluan tafsir yang dimaksud dalam penelitian ini adalah langkah pertama yang dilakukan dalam memulai tafsir dari setiap ayat, beberapa kitab tafsir mendahului tafsir satu surah dengan penjelasan mengenai gambaran umum surah sebagai contoh salah satu pelopor sistematika penyajian kitab tafsir modern seperti Aḥmad Musțafā al-Marāgi dalam tafsirnya secara general mendahului dengan penjelasan tentang golongan surah makkiyah atau madaniyah, penyebutan jumlah ayat dan alasan penamaan surah. ${ }^{43}$

\section{Tafsìir al-Munīr}

Pendahuluan tafsir yang dimaksud disini adalah langkah pertama yang dilakukan dalam memulai tafsir suatu surah, pada Tafsīi al-Munïr karya AGH. Daud Ismail, sistematika penyajian dimulai dengan mencantumkan nama surah dalam tulisan Arab

\footnotetext{
${ }^{37}$ Suryadilaga, Metodologi Ilmu Tafsir, 46

${ }^{38}$ Ahmad Syukri, Metodologi Tafsir Al-Qur'an Kontemporer dalam Pandangan Fazlur Rahman (Cet. I; Jakarta: Gaung Persada Press, 2007), 47.

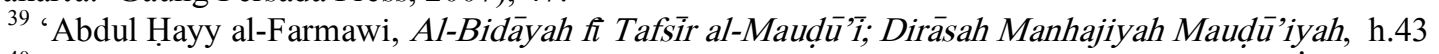

${ }^{40}$ Terdapat dua bentuk sistematika penyajian kitab tafsir: 1) sesuai urutan surah mushaf Úsmanī; 2) mengacu pada waktu turunnya wahyu. Kitab Tafsir berbahasa Bugis menggunakan metode yang pertama. Baca Islah Gusmian, Khazanah Tafsir Indonesia: dari Hermeneutika hingga Ideologi, (Yogyakarta, LKiS, 2013), 123.

${ }_{41}$ Baca Zahir bin Awad al-Almā'i, Dirāsāt fi al-Tafsìr al-Mauḍ̂̄’̄i li al-Qur’ān al-Karìm (Riyāḍ: t.p., 1404 H), h. 18. Baca juga M. Quraish Shihab, Sejarah dan Ulum Al-Qur'an, (Jakarta: Pustaka Firdaus, 2008), 172.

${ }^{42}$ Abd. Muin Salim, dkk., Metodologi Penelitian Tafsìr Maụ̂ū̄i (Yogyakarta, Pustaka al-Zikra, 2011), 41 .

${ }^{43}$ Lihat Aḥmad Musțfāa al-Marāgì, Tafsìr al-Marāgī, 30 Jilid, (Mesir: Syirqah Maktabah wa Maṭba'ah Musṭfā al-Babi் al-Ḥalābì wa Awlāduhu, 1946 M=1365 H) Jilid 1, 39.
} 
pada bagian atas, kemudian dibawah nama surah disebutkan urutan surah dan jumlah

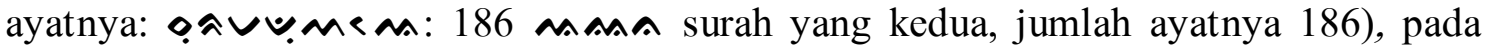
Kitab cetakan CV. Bintang Selatan ini, terdapat kesalahan dalam menyebutkan jumlah ayat QS. al-Baqarah yang sebenarnya berjumlah 286 ayat. ${ }^{44}$ Lihat gambar no.3 dibawah.

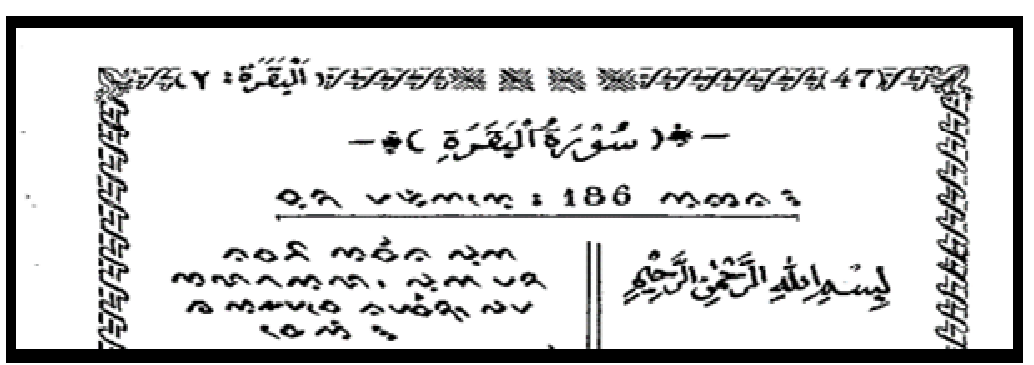

Gambar no. 3: Pendahuluan dalam Tafsīr al-Munir

\section{Tafsir al-Qur'ān al-Karìm}

Pada tafsir al-Qur'ān al-Karīm karya Tim MUI Sul-Sel, dalam menjelaskan QS. al-Baqarah sistematika penyajiannya dimulai dengan menjelaskan selayang pandang atau gambaran umum surah tersebut hal ini dijelaskan setiap memulai tafsir surah kecuali surah al-Fatihah sebagai surah pertama, dengan mencantumkan kalimat basmalah diikuti di bawahnya nama surah selanjutnya dalam gambaran umum surah dijelaskan bahwa "surah ini disebut surah al-Baqarah artinya sapi betina, berjumlah 286 ayat dan termasuk dalam kelompok surah madaniyah, dinamai surah al-Baqarah karena di dalamnya terdapat ayat yang menyebutkan kisah bani Israil kaum Yahudi) pada saat diperintahkan oleh Allah SWT untuk menyembelih sapi betina..."seperti gambar no. 4 berikut: $^{45}$

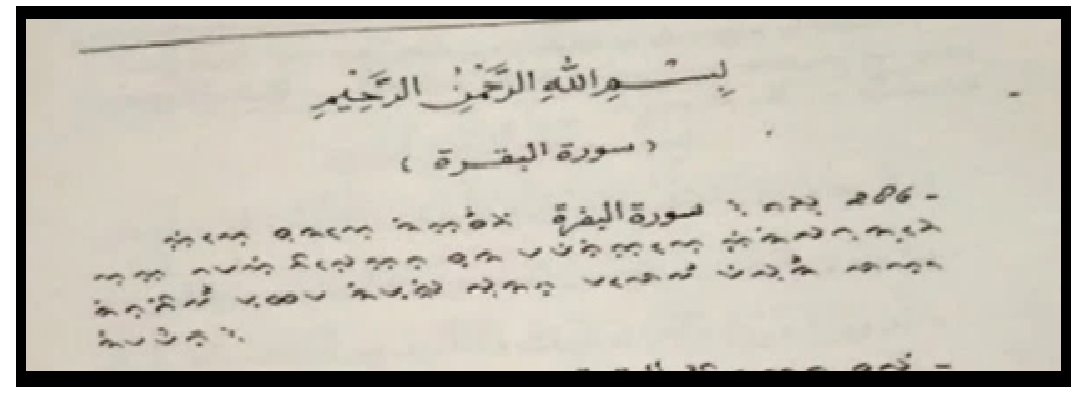

Gambar no. 4: Pendahuluan dalam Tafsīr al-Qur’ān al-Karìm

Perbandingan penyajian ayat dan terjemah pada kedua kitab tafsir dapat dilihat pada gambar no. 5 berikut:

\footnotetext{
${ }^{44}$ Daud Ismail, Tarjumanna Nennia Tapeséré Akorang Mabbicara Ogi, (Makassar: CV Bintang Selatan, t.th), 47.

${ }^{45}$ Majelis Ulama Indonesia Sulawesi-Selatan, Tapeséré, 21.
} 


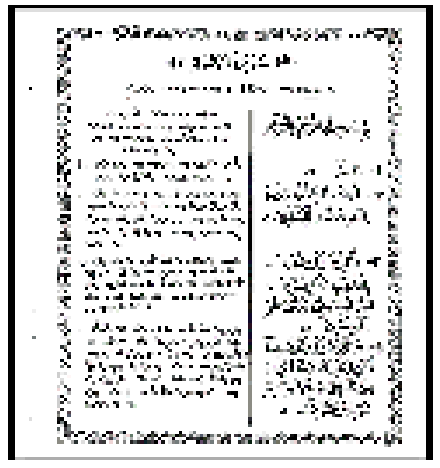

Tagleal Mritr.

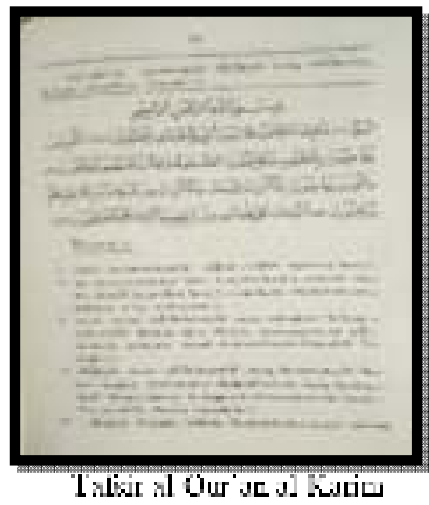

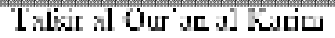

Gambar no. 5: Penyajian ayat dalam Tafsìr al-Munir dan Tafsìr al-Qur’ān al-Karim

\section{Tafsir ayat}

Tafsir ayat yang dimaksud ialah isi tafsir atau penjelasan makna dari setiap ayat dalam surah yang ditafsirkan.

\section{Tafsir al-Munir}

Dalam menjelaskan tafsir surah al-Baqarah, pada Tafsir al-Munī terlebih dahulu mengelompokkan ayat 1-13 dengan menampilkan ayat di sisi kiri kitab dan terjemahnya di sisi kanan kitab, kemudian menafsirkan QS. surah al-Baqarah dengan membagi ayat dalam beberapa kelompok berdasarkan tema yang dibahas, dapat dilihat pada gambar 6 berikut: ${ }^{46}$

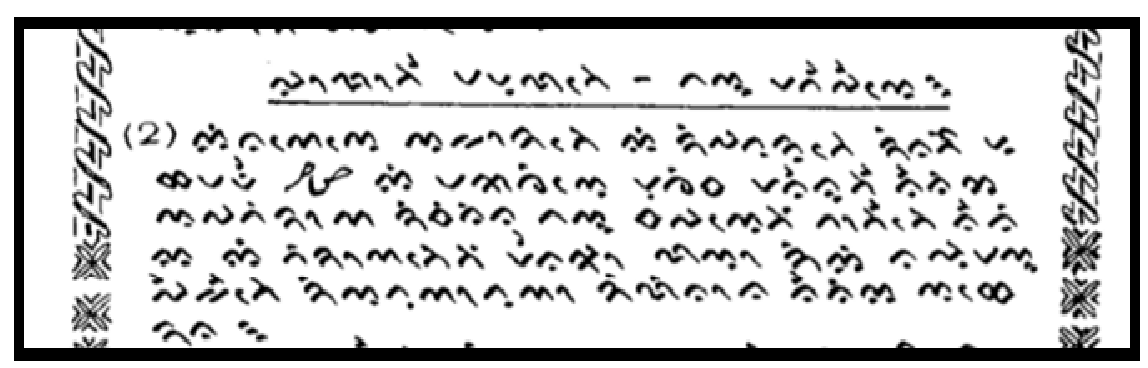

Gambar no. 6: Penjelasan Surat al-Baqarah dalam Tafsir al-Munir

Tulisan yang digaris bawahi merupakan tema dari ayat yang ditafsirkan yang berarti "golongan pertama- orang-orang beriman". Penafsiran ayat Al-Qur'an dilakukan setelah menulis ayat dan terjemahnya dengan ungkapan "へへルヘへヘ" (penafsirannya). ${ }^{47}$

\section{Tafsīr al-Qur'ān al-Karìm}

Pada Tafsīr al-Qur'an al-Karim, sebelum menafsirkan ayat dalam surah, lebih dulu menerangkan munasabah yakni hubungan antara surah sebelumnya dan surah

\footnotetext{
${ }^{46}$ Ismail, Tarjumanna Nennia Tapeséré, 50.

${ }^{47}$ Ismail, 24.
} 
yang akan ditafsirkan, sebab turunnya surah disebutkan jika ada dan dijelaskan sesuai penafsiran ayat terkait, kemudian mengelompokkan beberapa ayat untuk ditafsirkan dan diberi tema, sebagai contoh pengelompokan QS al-Baqarah/2: 1-5 dengan diberi

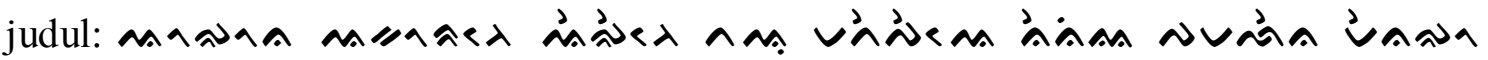
/ kedudukan al-Qur'an dan orang beriman serta balasan yang mereka peroleh, dengan memulai tafsir dengan ungkapan "^ฝે<૦<えへ" tafsirnya). ${ }^{48}$ Perbandingan sistematika penyajian tafsir kedua kitab dapat dilihat pada gambar no. 7 berikut: $^{49}$

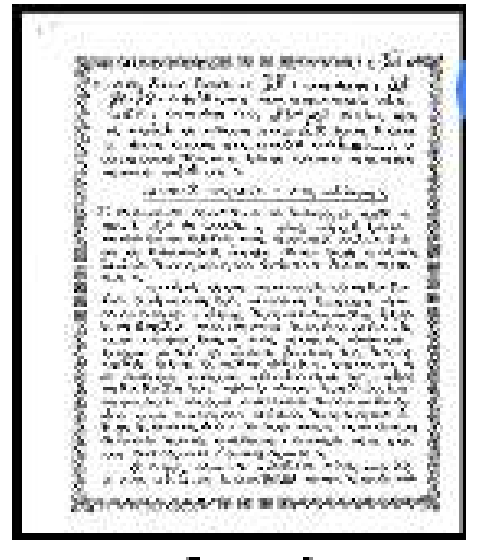

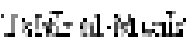

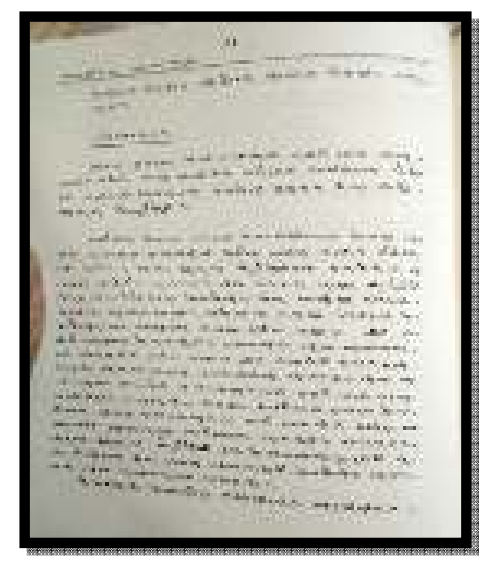

This

Gambar no. 7: Penyajian ayat dalam Tafsīr al-Munir dan Tafsìr al-Qur'ān al-Karim

\section{Penyebutan sumber tafsir atau referensi.}

Setidaknya ada empat sumber tafsir yang disebutkan al-Zahabi: ${ }^{50}$ a) tafsir alQur'an dengan al-Qur'an, b) tafsir al-qur'an dengan hadis Nabi saw, c) tafsir al-Qur'an dengan ijtihad, dan d) tafsir al-Qur'an dengan isra'iliyat riwayat-riwayat yang bersumber dari ahli kitab), namun dewasa ini seiring dengan perkembangan ilmu tafsir, para penyusun tafsir dalam menafsirkan ayat cenderung banyak mengutip atau mengembangkan penafsiran ulama sebelumnya, hal tersebut dilakukan selain sebagai bentuk pertanggung jawaban ilmiah juga disebabkan sebagai ekspresi kekaguman serta karena ulama tersebut memang layak dikutip pendapatnya dan dijadikan sebagai referensi, hal ini termasuk juga pada tafsir Bugis dan diakui sendiri oleh penyusunnya.

\section{Tafsīir al-Munir}

AGH. Daud Ismail dalam muqaddimah tafsirnya menyebutkan, diantara kitab yang dijadikan sebagai referensi dalam menafsirkan sebagai berikut: ${ }^{51}$

1) Tafsìi Jalālain.

\footnotetext{
${ }^{48}$ Majelis Ulama Indonesia Sulawesi-Selatan, Tapesere, 23

${ }^{49}$ Majelis Ulama Indonesia Sulawesi-Selatan, Tapeséré, 23; bandingkan, Daud Ismail, Tarjumanna Nennia Tapeséré Akorang Mabbicara Ogi.

${ }^{50}$ Muhammad Husain al-Żahaby, 'ilmu al-Tafsìi, (Kairoh: Dār al-Ma'ārif, 1919), 31-44.

${ }^{51}$ Muhyiddin, Tafsìr al-Munìr, Studi atas Pemikiran Akhlak AG.H. Daud Ismail, Disertasi, (Makassar: PPs UIN Alauddin, 2010), 83-85
} 
2) Tafs̄ir al-Marāgi ditulis oleh Aḥmad Musțafa al-Marāgi.

3) Tafsir Hāsyiyah al-Șâwi 'alā Tafs̄ir al-Jalālain Disusun oleh Syaikh al-Ṣāwi alMaliki.

4) Tafsir Fath al-Qadîr al-Jāmi' baina Fannai al-Riwāyah wa al-Dirāyah min 'Ilmi al-Tafsìr. oleh Syaukāni.

5) Tafsìr al-Kasysyāf atau dikenal dengan judul, al-Kasysyāf an Haqāiq al-Tanz̄̄ wa 'Uyūn al-Aqā wil fì wujūh al-Ta'w̄l, disusun oleh Abū al-Qāṣim Maḥmūd bin 'Umar al-Khawārizmi al-Ḥanafi al-Mu'tazili al-Zamạ̣syari.

\section{Tafsir al-Qur'ān al-Karim.}

Dalam muqaddimah Tafsìr al-Qur'ān al-Karim, AGH. Adul Muin Yusuf menyebutkan sepuluh karya tafsir sebagai rujukan, ${ }^{52}$ meskipun demikian diluar yang diebutkan itu ia juga mengutip Tafsir Mafatih al-Gaib yang ditulis oleh Fakhr al-Din al-Razi. ${ }^{53}$ Berikut karya tafsir yang dijadikan sebagai referensi:

1) Jāmi' al-Bayān fi Ta'wìl al-Qur'ān oleh Muhammad ibnu Jāir Abū Ja'far alTabari

2) Tafsìr al-Qur'ān al-Aẓim oleh Abū al-Fidā Ismāil ibnu 'Amr ibn Kasīir

3) Al-Dūr al-Mansiūr fì al-Tafsìr al-Ma'süur oleh 'Abd al-Rahmān Jalāluddin alSuyūtịi

4) Al-Jāmi li Aḥkām al-Qur'ān oleh Syams al-Dīn al-Qurtubì

5) Tafsìr al-Marāgī oleh Ahmad bin Musțāfa al-Marāgi

6) Anwār al-Tanzīl wa Asrār al-Ta'wīl oleh Nāṣir al-dīn al-Baidāāìi.

7) Tafsìr al-Qasimi oleh Muhammad Jamal al-Dīn al-Qasimì

8) Al-Tafsìr al-Wạụih oleh Muhammad Mạ̣mūd al-Hijāzi

9) Safwah al-Tafăsir oleh Muhammad 'Ali al-Ṣabūni

10) Al-Muntakhab fi Tafsìr al-Qur'ān al-Karìm dicetak oleh Lajnah al-Qur'ān wa al-Sunnah di Kairo.

Berdasarkan beberapa referensi yang disebutkan pada muqaddimah kitab tafsir Bugis, dapat dipahami bahwa penafsiran ayat yang dijelaskan dalam tafsir Bugis didominasi oleh kitab-kitab tafsir tersebut sebagai sumbernya, dan kalaupun terdapat penafsiran baik dalam bentuk tafsir al-Qur'an dengan al-Qur'an, tafsir al-qur'an dengan hadis Nabi Muhammad saw, tafsir al-Qur'an dengan ijtihad, dan tafsir alQur'an dengan isra'iliyat, dapat disimpulkan bahwa penafsiran itu pada dasarnya bersumber dari pemahaman penyusun kitab tafsir Bugis dari referensi yang disebutkan sebelumnya. Bahkan sering dijumpai penyusun tafsir Bugis menyebutkan nama Ulama yang penafsirannya dikutip, sebagai contoh pada gambar no. 8:

\footnotetext{
${ }^{52}$ Majelis Ulama Indonesia Sulawesi-Selatan, Tapesere, 2-3.

${ }^{53}$ Muhsin Mahfudz, "Tafsir al-Qur'an Berbahasa Bugis, 38-39.
} 


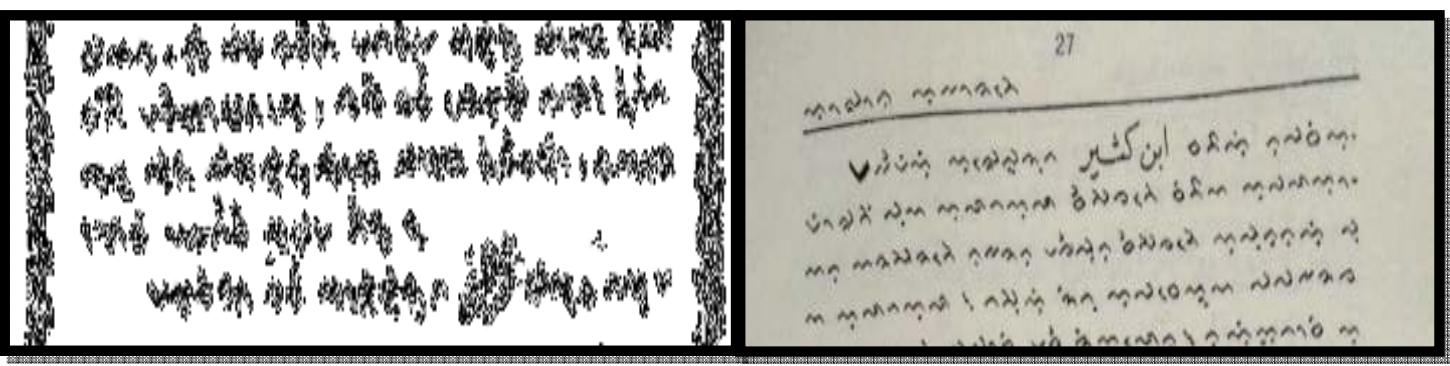

\section{Tafīir al-Munir Tafīir al-Qur'ān al-Karim}

Gambar No. 8: Pengutipan sumber dalam Tafsìr al-Muniri dan Tafsìr al-Qur'ān al-Karìm

Gambar pertama dalam Tafsīi al-Munìr, menjelaskan tafsir QS. Al-Baqarah ayat

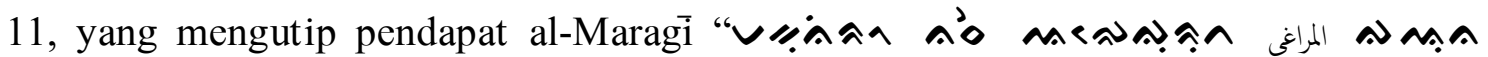

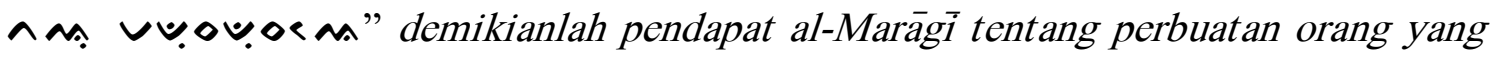
merusak.

Gambar kedua dalam Tafsìr al-Qur'ān al-Karim menjelaskan tafsir QS. al-

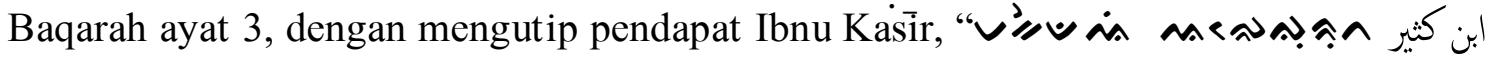
“ menurut Guru kita Ibnu Kasìr.

\section{Kutipan Hadis}

\section{Tafsir al-Munir}

Dalam mengungkap riwayat hadis terdapat berbagai bentuk penyajian dalam Tafsir al-Munir, berikut bentuk-bentuknya:

1) Menyebut mukharrij, sanad dan teks bahasa Arab terdapat pada saat menafsirkan Q.S. al-Anbiyā/21: 80 yang mengungkapkan doa Nabi Yūnus as. pada waktu keluar dari perut ikan. Ikan itu diperintahkan untuk melemparkan Nabi Yūnus a.s. ke pantai. AGH. Daud Ismail mengomentari dengan mengemukakan hadis yang diriwayatkan oleh dari البيهت

2) Menyebut mukharrij dan sanadnya dengan arti bahasa Bugis ketika menafsirkan Q.S. al-Anfāl/8: 38, tentang firman Allah swt. kepada Nabi Muhammad saw. agar menyampaikan kepada orang kafir bahwa apabila mereka telah masuk Islam, maka diampuni dosa-dosa yang telah lalu, bahkan tidak akan dituntut orang yang telah melakukan pembunuhan. ${ }^{55}$

3) Menyebut mukharrij tanpa menyebut sanad Ketika menafsirkan Q.S. alTaubah/9:16, AGH. Daud Ismail menulis hadis yang dikeluarkan oleh Bukhāri, Muslim, Abū Dāud dan Ibnu Mājah, tetapi tidak mencantumkan sanadnya, ${ }^{56}$

4) Menyebut teks hadis tanpa menyebut mukharrij dan sanadnya, menyebutkan hadis yang dijadikan sebagai rujukan, tanpa menyebut sanadnya. contohnya saat

\footnotetext{
${ }^{54}$ Ismail, Tafsïr al-Munir, 76..

${ }^{55}$ Ismail, Tafsìr al-Munīr, Juz 9, 215.

${ }^{56}$ Ismail, Tafsir al-Munir, Juz 11, 95.
} 
menafsirkan Q.S. Maryam/19: 60, orang yang melakukan perbuatan sehingga mengakibatkan dosa, lalu ia tobat, maka orang itu seperti halnya tidak pernah melakukan perbuatan dosa. ${ }^{57}$

\section{Tafsīr al-Qur'ān al-Karim}

Begitu juga dengan Tafsīr al-Qur'ān al-Karim, dalam mengungkap riwayat hadis terdapat berbagai bentuk penyajian diantaranya:

1) Penyebutan Mukharrij ${ }^{58}$ dan Rawi 'a' la ${ }^{-59}$ tanpa sanad, ${ }^{60}$ tedapat dalam penafsiran QS al-Baqarah/2: 222 mengenai haid istri, hanya menyebut Anas bin Malik sebagai Rawi a'lā dan imam Muslim sebagai Mukharrij. ${ }^{61}$

2) Penyebutan Rawi a'lā tanpa sanad dan Mukharrij. Sebagaimana dalam menafsirkan QS al-Baqarah/2: 255, tentang Bani Israil, hanya menyebutkan riwayat itu berasal dari Ibn Abbās. ${ }^{62}$

3) Penyebutan Mukharrij tanpa sanad, sebagaimana dalam menjelaskan QS alHujurāt/49: 12, disebutkan hadis itu bersumber dari Abū Dāwūd, meriwayatkan tentang kisah perjodohan Abū Hindun pembekam Nabi Muhammad saw. dengan anak perempuan dari suku Banū Bayạ̣̄ah. ${ }^{63}$

4) Tidak menyebutkan semua sanad dan Mukharrij-nya, sehingga tidak jelas sumbernya, Contoh model ini adalah dalam tafsir QS al-Baqarah/2: 232, tentang persoalan iddah. ${ }^{64}$

\section{Penutup}

\section{Tafsir al-Munir}

Di akhir penafsiran, AGH. Daud Ismail menutup dengan ungkapan ఎ $\boldsymbol{N} \dot{\boldsymbol{M}}^{2} \lambda$ /pengingat), tetapi hanya dilakukan untuk memberikan informasi tentang pandangan ulama terhadap suatu topik yang dibahas, contohnya:

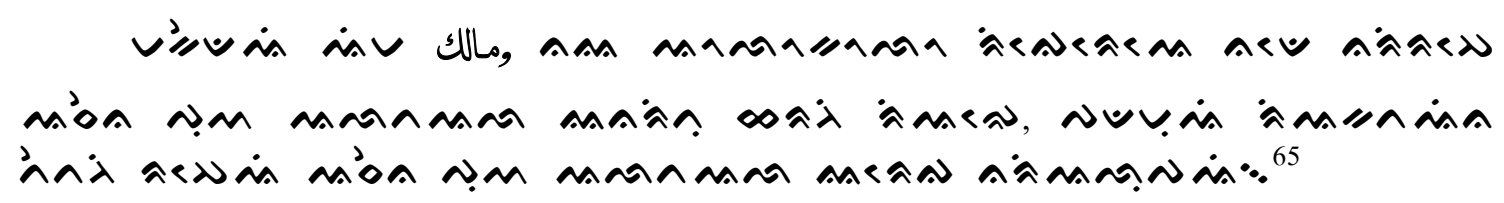

${ }^{57}$ Daud Ismail, Tafsir al-Munir, Juz 16, 69.

${ }^{58}$ Mukharrij adalah orang yang mencatat hadis tersebut dalam kitabnya atau disebut musnad dan sunan, misalnya imam Bukhari, Muslim, Ahmad bin Hambal, dan lainnya. Baca Syuhudi Ismail, Pengantar Ilmu Hadis (Bandung: Angkasa, 1994), 17.

${ }_{59}$ Dalam istilah ilmu hadis $R \bar{a} w i$ adalah mereka yang menyampaikan atau menulis hadis yang pernah didengarnya dari seorang guru, Sehingga kegiatannya menyampaikan hadis disebut meriwayatkan hadis dan pelakunya disebut rawi. Sedangkan rāwi 'a'lā adalah periwayat paling awal yang menerima hadis dari sumbernya yakni Rasulullah saw, lalu menyampaikannya kegenerasi selanjutnya atau semasanya, sahabat Rasulullah yang dimaksud disini kemudian para tabiin yang memiliki sanad sampai sahabat.

${ }^{60}$ Sanad dalam istilah ilmu hadis adalah sandaran hadis yang menghubungkan hingga ke Nabi atau sahabat, baca Abdul Majid Khon, Ulumul Hadis (Cet. VI; Jakarta: Bumi Aksara, 2010), 97.

${ }^{61}$ Majelis Ulama Indonesia Sulawesi-Selatan, Tapesere Akorang Mabbasa Ogi, Jilid 1, 319

${ }^{62}$ Majelis Ulama Indonesia Sulawesi-Selatan, Tapesere, 391.

${ }^{63}$ Majelis Ulama Indonesia Sulawesi-Selatan, Tapesere Akorang Mabbasa Ogi, Jilid 10, 392.

${ }^{64}$ Majelis Ulama Indonesia Sulawesi-Selatan, Tapesere Akorang Mabbasa Ogi, Jilid 1, 340.

${ }^{65}$ Daud Ismail, Tafsir al-Munir, Juz 6, 90. 
Transliterasi:

"Makkedai imām Mālik, naiyya olo kolo rigérēé nadē narirampé asenna Puang Allataāla iyanaritu haranngi rianré, padamui riakkattainna tettanngi rampéi asenna Puang Allataāla iyaréga nariallupai”.

Artinya:

"Imām Mālik berkata, adapun binatang yang disembelih dengan tidak menyebutkan nama Allah swt. haram dimakan, baik disengaja atau lupa menyebut nama Allah swt".

Kemudian dalam menutup penafsiran satu Juz, AGH. Daud Ismail selalu mengucapkan syukur al-Hamdulillah sebagai tanda kesyukuran, sebagai contoh

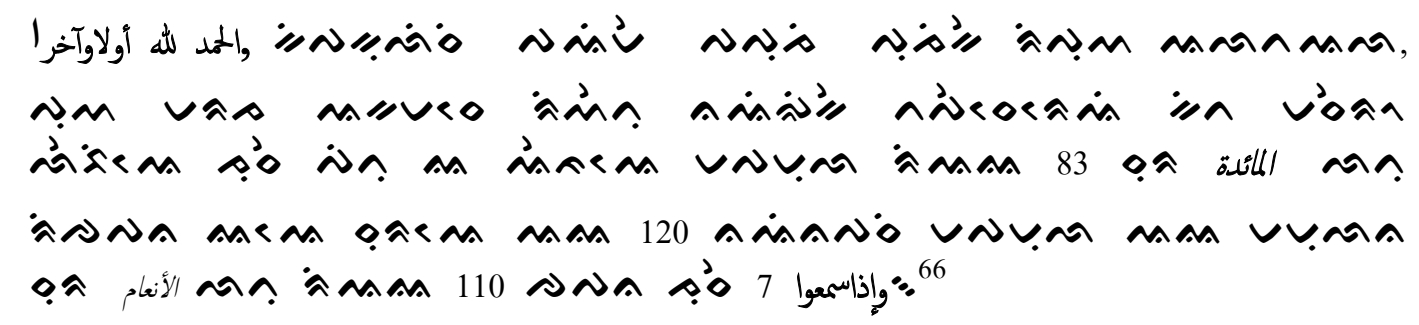

Transliterasi:

" المحد لله أولا وآخرا , kipakkūlissi paimeng pappuji-pujikkeng ri Puang Allataāla, Puang maraja akkamasé riwettu nainrikkeng tapeséréi kitta masero lebbié juse pitu iya engkaé mappammūla ri aya 83 surah المائدة lattu ricappa'na iyaé suraé ayat 120, nainappasi mappammula aya mamulanna surah الأنعام lattu ri aya 110 cappanna juse 7 وإذاسمعوا

Artinya:

الممد له أولاوآخرا , saya mengulangi kembali rasa syukurku kepada Allah swt. yang telah memberikan hidayah untuk menafsirkan kitab yang mulia ini juz 7, dimulai dengan ayat 83 surah العائدة sampai akhir surah ayat 120 kemudian dilanjutkan ayat pertama surah الأنعام sampai ayat 110 akhir juz 7 إذإسمعوا

Selanjutnya menyebutkan hari, tanggal dan tahun penulisan, baik tahun hijriyah maupun tahun masehi setiap akhir penulisan juz:

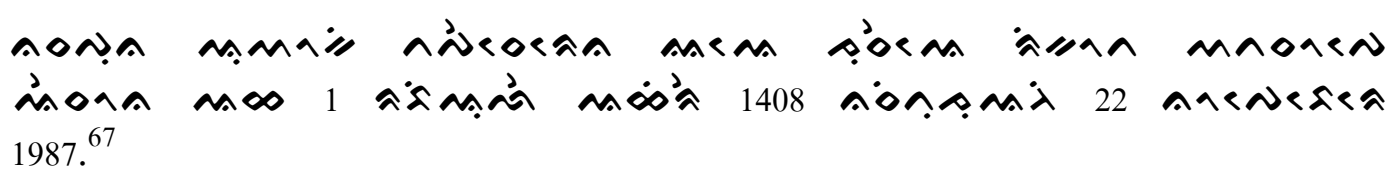

Transliterasi:

Nasappūna uwōki tapeséréna iyae juseé ri kota Watansoppeng essōna ahad 1

Rabiaul Akhir 1408 nasitujuanngi 22 Nopember 1987.

\footnotetext{
${ }^{66}$ Ismail, Tafsir al-Munï, Juz 7, 201.

${ }^{67}$ Ismail, Tafsir al-Munir, Juz 7, 201.
} 
Artinya:

Telah saya mselesaikan tafsir juz ini, di kota Watansoppeng hari Ahad tanggal 1 rabi'ul a khir 1408 bertepatan dengan tanggal 22 Nopember 1987 M.

Penulisan hari, tanggal, dan tahun dilakukan oleh AGH. Daud Ismail setiap selesai menulis satu dengan menggunakan tahun hijriyah dan miladiyah, dimulai pada juz pertama sampai juz terakhir.

\section{Tafsīi al-Qur'ān al-Karim}

Pada akhir tafsir surah dalam kitab tafsir al-Qur'ān al-Karim cenderung langsung melanjutkan ke penafsiran surah selanjutnya tanpa diberi penutup, adapun pada akhir Juz ditutup dengan ungkapan " والله اعلم بالصواب" sebagaimana dalam gambar no. 9.68

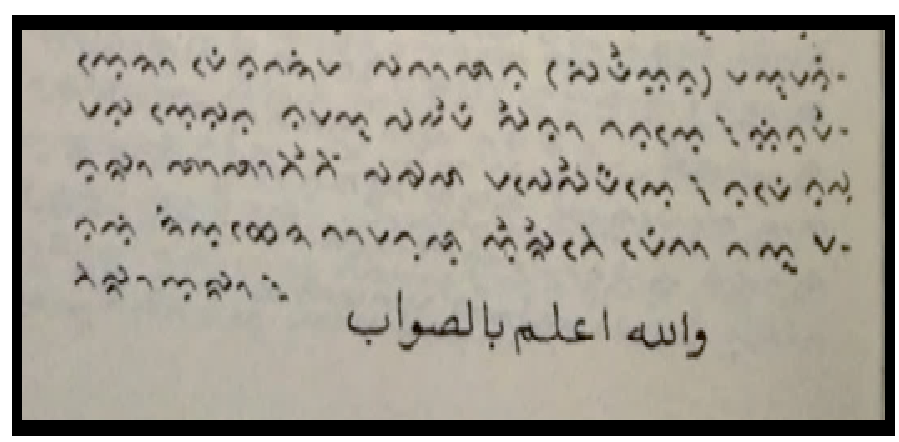

Gambar no. 9: Penutup dalam Tafsìr al-Qur'ān al-Karim

\section{Penutup}

Dari beberapa pembahasan di atas dapat disimpulkan bahwa metodologi Kitab Tafsìr al-Munïr dan Kitab Tafsir al-Qur'ān al-Karim, jika dilihat dari aspek penyajiannya termasuk dalam kategori tafsir Tahlili, dengan sistematika penyajian runtut, dengan mengikuti urutan mushaf Usmani, yaitu penafsirannya dimulai dari surah al-Fātihạ sampai akhir surah al-Nās, namun jika dilihat dari segi uraian-urain ayat yang ditafsirkan, aspek analisisnya menggunakan metode Ijmāli.

Perbedaan antara Tafsìr al-Munir dan Kitab Tafsìr al-Qur'ān al-Karim terletak pada awal penafsirannya. Kitab Tafsir al-Qur'ān al-Karim diawali dengan penjelasan tentang gambaran umum surah meliputi jumlah ayat dan alasan penamaan surah tersebut, sedangkan pada Kitab Tafsīr al-Munīr langsung dimulai dengan pemaparan ayat dan terjemahnya dalam bahasa bugis. Sementara kedua kitab tafsir bugis tersebut dalam menafsirkan ayat, sama-sama mengelompokkan terlebih dahulu beberapa ayat dengan tema tertentu dan diberi judul berdasarkan tema ayat yang dikelompokkan tersebut, dan selalu mencantumkan nama Ulama tafsir yang pendapatnya dikutip dalam penafsiran ayat.

${ }^{68}$ Majelis Ulama Indonesia Sulawesi-Selatan, Tapeséré. 562. 
Dalam pencantuman hadis, kedua kitab tafsir tidak memiliki pola tertentu terkait dengan pencantuman sanad dan matan hadis, atau hanya salah satunya saja, dalam pencantuman sanad hal tersebut tergantung pada konteks penafsiran, apakah perlu atau tidak perlu dicantumkan. Sementara pada penutup tafsir surah, pada Tafsir al-Munir, dijelaskan tentang kesimpulan atau hikmah dari topik yang terdapat dalam surah yang ditafsirkan, dan pada akhir juz disebutkan hari tanggal, bulan dan tahun penulisan serta ditutup dengan ungkapan "alhamdulillah", adapun pada Tafsīr al-Qur'ān al-Karìm, setiap juz ditutup dengan ungkapan "wallāhu a'lam bi al-sawāb”.

\section{DAFTAR PUSTAKA}

Ahmad, Abd. Kadir, Ulama dalam Dinamika Sosial Sulawesi Selatan, Disertasi Makassar: PPs. Universitas Hasanuddin Makassar, 2005.

Al-Almā'i, Zahir bin Awad, Dirâsât fi al-Tafsîr al-Mauḍ̂h'î li al-Qur'ān al-Kan̂m, Riyāḍ: t.p., 1404 H.

Al-Farmawi, 'Abdul al-Hayy, Muqaddimah fì al-Tafsîr al-Mauḍ û'i, Kairo: Al-Hadârah al-Arabiyyah, 1977

Al-Farmawi, 'Abdul Hayy, Al-Bidâyah fî Tafsîr al-Mauḍ̣̂'î; Dirâsah Manhajiyah Maudû'iyah, terj. Rosihan Anwar, Metode Tafsir Mauḍ̂h'î; Dan Cara Penerapannya, Cet. I; Bandung: CV. Pustaka Setia, 2002

Al-Marāgi, Aḥmad Musțafā, Tafsîr al-Marâgî, 30 Jilid, (Mesir: Syirqah Maktabah wa Maṭba'ah Musțầ al-Babî al-Ḥalâbî wa Awlāduhu, 1946 M=1365 H

Ar-Raffany, Wahidin, AG. H. Abdul Muin Yusuf; Ulama Kharismatik Dari Sidenrang Rappang, Cet. I, Sidrap: LAKPESDAM SIDRAP, 2008.

Baihaki, Egi Sukma. "Penerjemahan Al-Qur'an: Proses Penerjemahan Al-Qur'an di Indonesia, Jurnal Ushuluddin, 25, no. 1 (2017): 44-53. http://dx.doi.org/10. 24014/jush.v25i1.2339

Gusmian, Islah, Khazanah Tafsir Indonesia, dari Hermeneutika hingga Ideologi Yogyakarta, LKiS, 2013.

Heryani, Yani. "Teknik Menerjemahan Al-Qur'an Ke Dalam Bahasa Sunda”, AlTsaqafa: Jurnal Ilmu Peradaban Islam 16 no. 2 (2019): 167-175. https://doi.org/10.15575/al-tsaqafa.v16i2.5018

Ismail, Daud, Tarjumanna Nennia Tapeséré Akorang Mabbicara Ogi, Tafsïr al-Munï, 10, Makassar: CV. Bintang Lamumpatue, 2001

Ismail, Daud, Tarjumanna Nennia Tapeséré Akorang Mabbicara Ogi, Tafsïr al-Munïr. 10, Makassar: CV. Bintang Selatan, t.th.

Ismail, Syuhudi, Pengantar Ilmu Hadis Bandung: Angkasa, 1994.

Kabry, Abd. Muiz, Sejarah Kebangkitan dan Perkembangan Darud Da'wah wal Irsyad DDI), Pondok Pesantren DDI Ujung Lare, Pare-Pare: 1983.

Khon, Abdul Majid, Ulumul Hadis Cet. VI, Jakarta: Bumi Aksara, 2010. 
Lukman, Fadhli. "Studi Kritis Atas Teori Tarjamah Al-Qur'an dalam 'Ulumul Qur'an", Al-A'raf: Jurnal Pemikiran Islam dan Filsafat 13 no. 2 (2016): 167190. http://10.22515/ajpif.v13i2.262

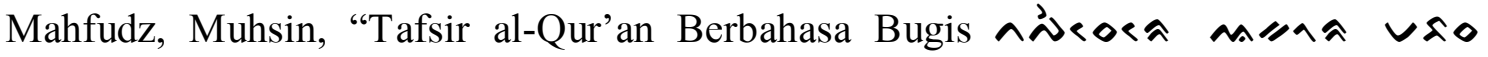
ма৯) Karya AGH. Abd. Muin Yusuf". AL-FIKR: Jurnal Pemikiran Islam 15 no. 1 (2011): 34- 47.

Mahfudz, Muhsin, Transformasi Tafsir Lokal, Upaya Pemetaan Metodologi Karya Tafsir Ulama Sulawesi Selatan (1930-1998), Disertasi (Makassar: PPs. UIN Alauddin, 2015)

Majelis Ulama Indonesia Sulawesi-Selatan, Tapesere Akorang Mabbasa Ogi, Tafsir alQur'an al-Karim, Jilid 1 Ujung Pandang: MUI Sul-Sel, 1988.

Majelis Ulama Indonesia Sulawesi-Selatan, Tapeséré Akorang Mabbasa Ogi, Tafsïr alMu'in, Sidrap: Khadim Al-Urwatul Wutsqa, 2008.

Muḥammad Ḥusain al-Żahaby, 'ilmu al-Tafsîr, Kairoh: Dâr al-Ma’ārif, 1919.

Muhyiddin, Tafsîr al-Munîr, Studi atas Pemikiran Akhlak AG.H. Daud Ismail, Disertasi, Makassar: PPs UIN Alauddin, 2010.

Mursalim, “Corak Pemikiran Tafsir Ulama Bugis Suatu Kajian Kitab Tafsir al-Qur'an Karim Karya Majelis Ulama Indonesia MUI) Sulawesi Selatan”, Disertasi.

Mursalin dan Abbas, "Vernakularisasi Al-Qur'an di Tanah Bugis: Tinjauan Metodologis Terjemahan Al-Qur'an Karya Anregurutta Yunus Maratan" AlIzzah: Jurnal Hasil-hasil Penelitian 15 no. 2 (2020): 49-62. http://dx.doi.org/ 10.31332/ai.v0i0.2179

Nst, Hanapi, "Metodologi Terjemahan Al-Qur'an dalam Al-Qur'an dan Terjemahnya Bahasa Batak Angkola”, Kontemplasi: Jurnal Ilmu-ilmu Ushuluddin 7, no. 01 (2019): 1-18. https://doi.org/10.21274/ kontem.2019.7.1.1-18

Pelras, Christian, Manusia Bugis, diterjemahkan oleh, Abdil Rahman Abu, Hasriadi, dan Nuhardy Sirimorok, Jakarta: Nalar \& Forum Jakarta-Paris: 2006.

Rohmana, Jajang A. "Alquran Dan Bahasa Sunda Populer: Respons Generasi Milenial Terhadap Terjemahan Alquran Bahasa Sunda"Al-Bayan: Jurnal Studi AlQur'an dan Tafsir 4 no. 2 (2019): 93-110. https://doi.org/10.15575/albayan.v4i2.8008

Ruslan, Muhammad dan Waspada Santing, ed., Ulama Sulawesi Selatan: Biografi Pendidikan dan Dakwah Cet. I; Makassar: Komisi Informasi dan Komunikasi MUI Sulawesi Selatan, 2007.

Salim, Abd. Muin, dkk., Metodologi Penelitian Tafsìr Maudù'̇̄ Yogyakarta, Pustaka al-Zikra, 2011,

Shihab, M. Quraish, Membumikan Al-Qur'an; Fungsi dan Peran Wahyu dalam Kehidupan Cet. XIII. Bandung, Mizan, 1998.

M. Quraish, dkk. Sejarah dan 'Ulumu al-Qur'an, Jakarta, Pustaka Firdaus, 2008.

Suryadilaga, M. Fatih, Metodologi Ilmu Tafsir, Yogyakarta: Teras, 2005 
Syukri, Ahmad, Metodologi Tafsir Al-Qur'an Kontemporer dalam Pandangan Fazlur Rahman, Cet. I; Jakarta: Gaung Persada Press, 2007

Teng, H. Muhammad Bakar Akkase, Filsafat Dan Sastra Lokal Bugis) Dalam Perspektif Sejarah.

Yusuf, KH. Abdul Muin, Tafsirir al-Mu'īn, Tapeséré Akorang Mabbasa Ogi Sidrap: PP Al-Urwatul Wutsqa, t.th 